\title{
The diploporite blastozoan Glyptosphaerites (Echinodermata: Blastozoa) and the origin of diplopores
}

\author{
Christopher R. C. Paul ${ }^{\mathrm{a}}$ and Ursula Toom ${ }^{\mathrm{b}}$ \\ ${ }^{a}$ School of Earth Sciences, University of Bristol, Bristol, UK; glcrep@bristol.ac.uk \\ ${ }^{\mathrm{b}}$ Department of Geology, School of Science, Tallinn University of Technology, Ehitajate tee 5, 19086 Tallinn, Estonia; \\ ursula.toom@taltech.ee
}

Received 6 May 2021, accepted 25 October 2021, available online 16 November 2021

\begin{abstract}
Glyptosphaerites is a stemless, directly attached diploporite characterized by five ambulacra that have multiple facets and extend over the theca, but entirely lack flooring and cover plates. The food grooves lack any systematic relationship to the underlying thecal plates and grow out from a mouth with a frame of six plates; five radial circumorals and a sixth interradial plate in the CD interambulacrum. The mouth is covered by a palate of eleven palatal plates. These characters are shared by most Sphaeronitidae, whereas traditionally Glyptosphaerites has been associated with diploporites that possess a stem and ambulacra with biserial flooring plates that alternate, left and right, and each of which supports a single brachiole facet. Such diploporites are characterized by Protocrinites, which has cover plates over its ambulacra and mouth but lacks a palate. Glyptosphaerites and Protocrinites are typical of two major divisions within the Diploporita, here called the Anambulacralia and Ambulacralia, respectively. The oldest identified anambulacralian is the middle Cambrian 'eocrinoid' Lichenoides.

Diplopores of Glyptosphaerites leuchtenbergi arose on plate sutures as a single perpendicular canal like an epispire. This became incorporated into one plate as a second perpendicular canal developed on the suture. Further plate growth increased the separation of the two perpendicular canals until a standard distance was established when both canals became incorporated into the plate. Thus, the axes connecting perpendicular canals are perpendicular to plate sutures. In G. leuchtenbergi, diplopores were preferentially incorporated into one plate, often resulting in diplopores being concentrated in the adoral halves of thecal plates.
\end{abstract}

Key words: Blastozoa, Anambulacralia nov., Ambulacralia nov., Sphaeronitoida, Glyptosphaerites, Protocrinitoida.

\section{INTRODUCTION}

In the Treatise (Kesling 1968), Glyptosphaerites Müller, 1854 was regarded as the type genus of a diploporite superfamily, the Glyptosphaeritida Bernard, 1895 (now formally Glyptocystitoida) characterized by extensive ambulacra that spread over the theca. The superfamily included four families: Glyptosphaeritidae, Dactylocystidae, Protocrinitidae and Gomphocystitidae. The first and last are directly attached diploporites, whereas the Protocrinitidae and Dactylocystidae possess functioning stems, at least as juveniles (Bockelie 1984). Furthermore, all but the monotypic Glyptosphaeritidae have ambulacra with a regular structure. The mouth is surrounded by six interradial, perioral plates (Paul 1971), two in the posterior CD interambulacrum of Carpenter $(1884,1891)$ and one each in the other interambulacra (Fig. 1B). The food grooves leave the mouth along sutures between perioral plates and immediately give rise to ambulacral plates, each of which bears a single brachiole facet. The perioral plates lack facets in all families except the Gomphocystitidae. Most gomphocystitid ambulacra spiral down the theca and have facets only on the outside of the spiral (left side of the ambulacra looking in the direction of growth). In taxa where ambulacra spiral in opposite directions, such as the flattened 'eocrinoid' Haimacystis Sumrall et al., 2001, the brachioles are confined to the outside of the curves and so on opposite sides of the two ambulacra. In all other genera of Protocrinitidae and Dactylocystidae, the ambulacral plates alternate regularly in a biserial arrangement. In addition, all but the protocrinitid genus Estonocystis Jaekel, 1918 have one facet per ambulacral plate. Furthermore, small ambulacral cover plates occur in Protocrinites (Fig. 2B top).

In contrast, Glyptosphaerites has a mouth frame composed of six circumoral plates (Paul 1973); five are radial and bear the food grooves centrally as they leave the mouth, the sixth is interradial in the CD interambulacrum 

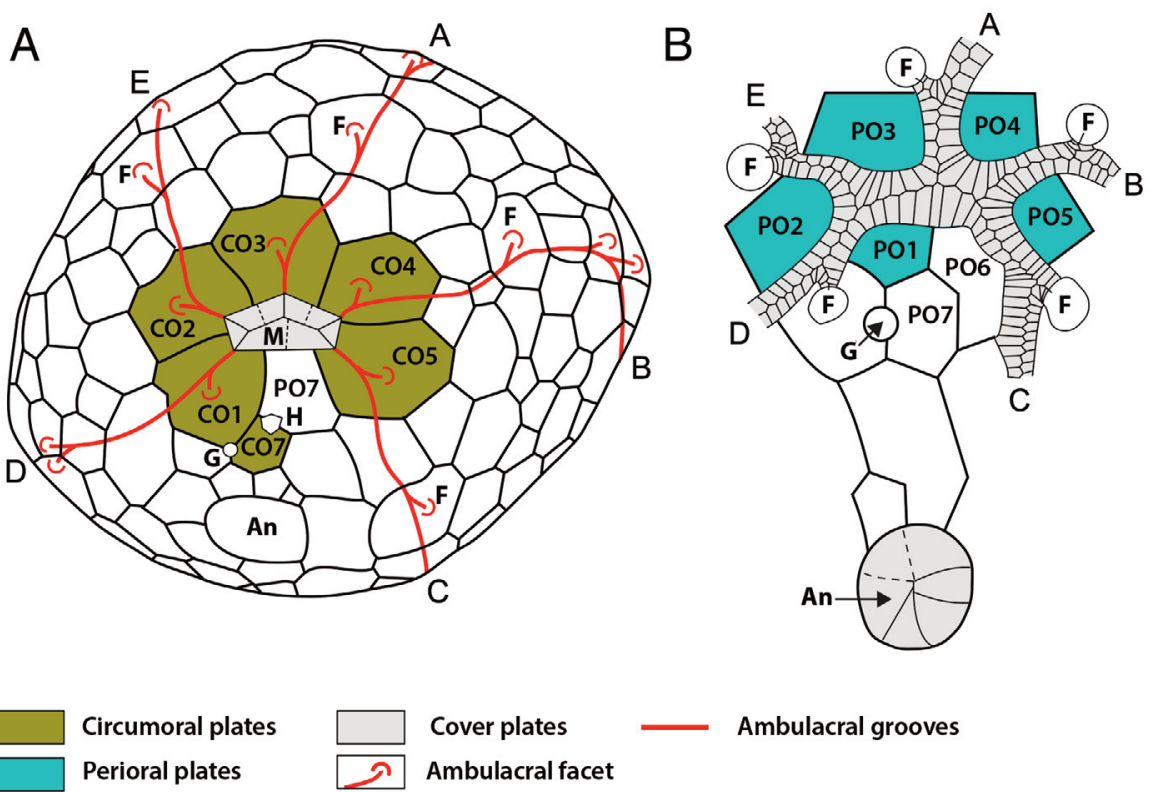

Cover plates

Ambulacral facet

Fig. 1. Drawings of oral areas and ambulacra of (A) Glyptosphaerites leuchtenbergi (Volborth, 1846); (B) Protocrinites rugatus Bockelie, 1984. In Glyptosphaerites (A), the mouth (M) is covered by a small number of large cover plates called palatals, and surrounded by six plates. Five radial circumorals (CO1-CO5) bear the first ambulacral facet (F), which always branches to the left of the extensive food grooves. The sixth plate (PO7) shares the hydropore $(\mathrm{H})$ with plate CO7. The gonopore $(\mathrm{G})$ is associated with circumoral CO1. The anus (An) is widely separated from the mouth. In Protocrinites (B), the mouth is covered by small biserial cover plates and surrounded by six interradial plates called periorals (PO1-PO6). Broad food grooves give rise to brachiole facets (F) on the first 'adambulacral' plates. The first facets always branch left. The gonopore (G) is shared by perioral PO7 and the first adambulacral plate of ambulacrum D. The anus is widely separated from the mouth and covered by a simple anal pyramid (An). In Glyptosphaerites, food grooves lack cover plates and ambulacral facets occur randomly on underlying thecal plates. In Protocrinites, biserial cover plates extend along the food grooves, which give rise regularly to brachioles alternately left and right. A-E ambulacra labelled according to Carpenter's (1884, 1891) system. A, redrawn from Regnéll (1945, fig. 18a, p. 155); B, redrawn from Bockelie (1984, fig. 11A, p. 15).

(Fig. 1A) and homologous with perioral PO7 of protocrinitids (Fig. 1B). The food grooves extend widely over the thecal surface and bear occasional side branches that end in small facets for presumed brachioles, but none has been preserved. The only regular feature is that each radially-positioned circumoral bears a single facet left of the main food groove (Fig. 1A). Thereafter facets occur sporadically. They do not alternate regularly. They bear no relationship to the thecal plates on which they were developed (Fig. 3). Commonly facets to the left of the main food groove are close to it, whereas those on the right are at the tips of extensive lateral branches (Figs 3, 4), but otherwise no generalizations can be made about ambulacral structure. The underlying plates may have a food groove but no facet, both, or more than one facet, sometimes from different ambulacra. Furthermore, the food grooves appear to be etched out of the surfaces of thecal plates. They have no flooring plates, nor cover plates. The mouth itself is covered with a small pyramid of interradial plates, three in the CD interambulacrum and two each in the other interambulacra (Fig. 5). This is a palate-like structure (Paul 1971) of immovable cover plates. The structure of the mouth, the palate and the ambulacra differ significantly from all the other supposed 'glyptosphaeritoids'.

On the other hand, the sphaeronitoid cystoid families Sphaeronitidae and Holocystitidae are characterized by a palate of six interradial plates covering the mouth, two in the CD interambulacrum and one each in the other four (Paul 1971, 1973; Frest 1983; Bockelie 1984; Frest et al. 2011), an oral frame either of perioral plates (Holocystitidae; Paul 1971; Frest 1983) or circumoral plates (Sphaeronitidae; Paul 1973) and food grooves that lack flooring or cover plates (Paul 2017). In the sphaeronitid genera Eucystis Angelin, 1878 and Tetreucystis Bockelie, 1984, the food grooves may extend widely over the theca (Prokop 1964; Paul 1973; Bockelie 1984) as they do in Glyptosphaerites. In summary, despite being the type genus for the superfamily Glyptosphaeritoida, Glyptosphaerites lacks many of the key characters that supposedly define that taxon, but instead it shares several key characters defining the superfamily Sphaeronitoida. 

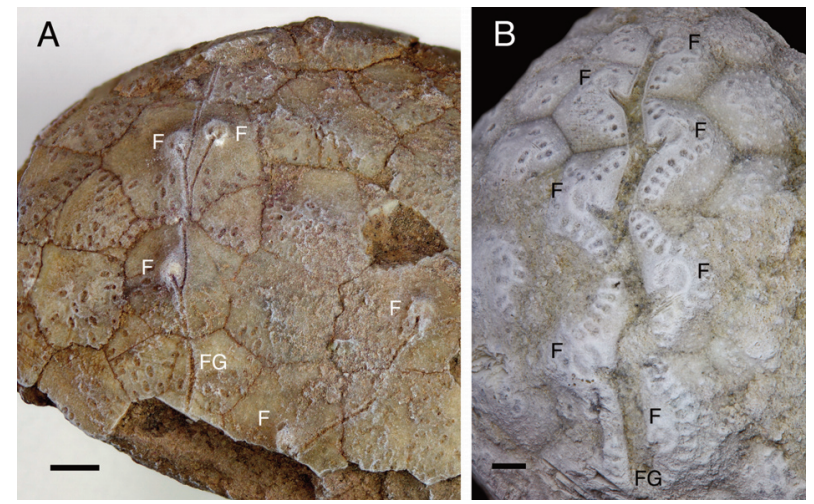

Fig. 2. Food grooves of (A) Glyptosphaerites leuchtenbergi (Volborth, 1846), NHMUK E28694, 'near St Petersburg, Ordovician' and (B) Protocrinites oviformis Eichwald, 1840, GIT 540-67 (Sõjamäe, Estonia; Tatruse Formation, Haljala Regional Stage, Sandbian), to show difference in food grooves, which grew up the figure in both cases. The food grooves (FG) in (A) are very narrow, lack floor or cover plates, and give rise irregularly to ambulacral facets (F). Food grooves and facets bear no consistent relationship to underlying thecal plates. So, in the left-hand food groove, the first thecal plate bears a food groove, the second two food grooves and one facet, the third three food grooves and two facets and the fourth just a food groove. The main food groove is wider in $(\mathbf{B})$ and tapers distally, where ledges for the insertion of cover plates are revealed. Each alternating adambulacral plate bears a single brachiole facet. The penultimate right-hand and ultimate left-hand facets show narrow food grooves descending into the deep channel of the main ambulacral groove. Note the irregular diplopores in (A), compared with regular arcs of diplopores on both sides of the ambulacrum in (B). A, whitened with fingerprint powder, B, with ammonium chloride. Scale bars $=2 \mathrm{~mm}$.

So, Paul (1984, p. 65) formally transferred the genus Glyptosphaerites to the family Sphaeronitidae and renamed the 'Glyptosphaeritoida' the Protocrinitida (now formally the Protocrinitoida). Even so, this was when describing a new species of gomphocystitid diploporite. No formal redescription of Glyptosphaerites was given. Indeed, the last significant description of Glyptosphaerites was that of Regnéll (1945, p. 153 et seq.). Later, Paul \& Fone (1997, p. 156) repeated the substitution of the name Protocrinitida for Glyptosphaeritida, in describing a new species of Eumorphocystis Branson \& Peck, 1940.

The ambulacra of the Protocrinitoida apparently correspond to the axial skeleton under the Extraxial-Axial Theory (EAT) of Mooi \& David (1997) and David \& Mooi (1998). The EAT identifies three regions of skeletal plates in any echinoderm. The axial skeleton is derived from the larval rudiment, is associated with the water vascular system, and plates are added terminally during growth in a precise order referred to as the 'Ocular Plate Rule'. The extraxial skeleton is derived from the non-

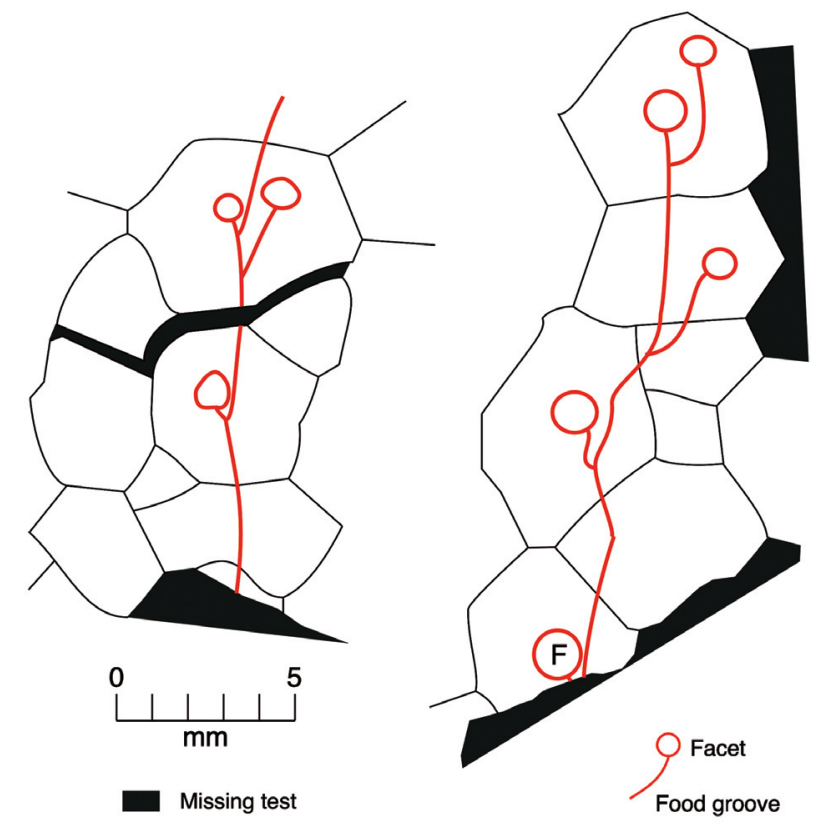

Fig. 3. Camera lucida drawings of two food grooves in Glyptosphaerites leuchtenbergi (Volborth, 1846), NHMUK E28694, 'near St Petersburg, Ordovician', showing lack of relationship to underlying thecal plates. $\mathrm{F}$ is an ambulacral facet.

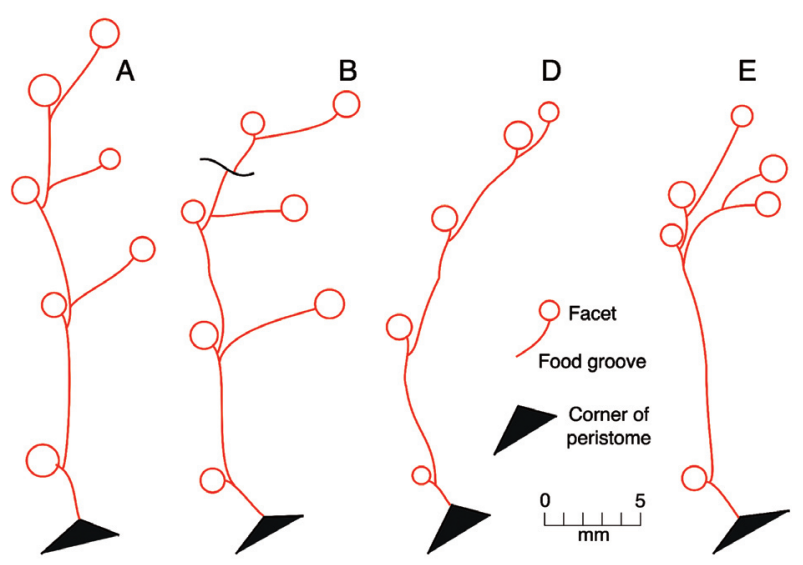

Fig. 4. Camera lucida drawings of four food grooves in Glyptosphaerites leuchtenbergi (Volborth, 1846), NHMUK E28696, 'near St Petersburg, Ordovician', showing the branching patterns, which include a left facet immediately adjacent to the peristome, short left branches and longer right branches. Right branches may branch again (ambulacrum E). A, B, D and E, ambulacra under Carpenter's $(1884,1891)$ system.

rudiment parts of the larval echinoderm and plates are added in a variety of ways during subsequent growth. The extraxial skeleton is further divided into a perforate part in which the primary thecal orifices (gonopore, hydropore 

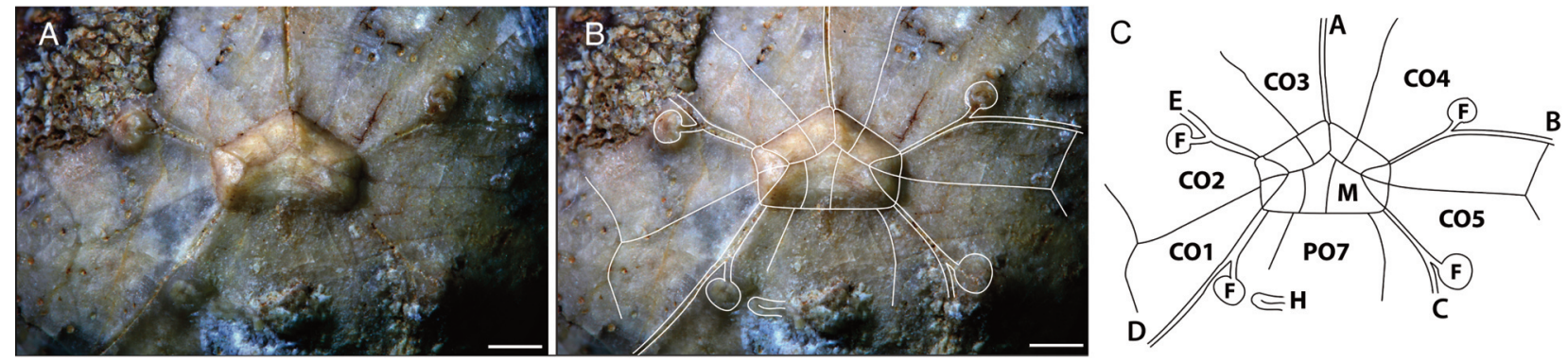

Fig. 5. Oral area of Glyptosphaerites leuchtenbergi (Volborth, 1846), TUG 1727-27 (Valaste, Estonia; Kandle Formation, Aseri Regional Stage, Darriwilian), showing the pentagonal peristome covered by a palate of eleven plates, food grooves (double lines) and circumoral plates (CO1-CO5). A, photograph of the oral area. B, photograph with interpretation of plates and food grooves. C, interpretation. A-E, ambulacra under Carpenter's $(1884,1891)$ system; F, ambulacral facet; H, hydropore; M, mouth covered by the palate. The mouth is surrounded by five radially positioned plates $(\mathrm{CO} 1-\mathrm{CO} 5)$ bearing food grooves centrally. A sixth interradial plate (PO7) occurs in the posterior (CD) interambulacrum. This type of oral frame characterizes the family Sphaeronitidae. Note that ambulacrum A lacks the first facet. Scale bars $=1 \mathrm{~mm}$.

and anus) occur as well as various respiratory pore structures (Sprinkle \& Guensburg 2001), and an imperforate part that lacks orifices and pore structures. These three subdivisions of the skeleton can be recognized in most echinoderms including fossils. In the Protocrinitoida, the ambulacral plates were added terminally under the 'Ocular Plate Rule' (David et al. 1995) and so appear to be axial skeleton. On the other hand, all the ambulacral plates including the orals, bear respiratory pore structures called diplopores, which suggests the ambulacral plates are part of the perforate extraxial skeleton. In addition, the gonopore and hydropore are associated with 'oral' plates and so would seem to be part of the perforate extraxial skeleton. At least some of the 'orals' are also first ambulacral plates. The presence of ambulacral diplopores may be explained by their mode of development (see below), but we accept that diploporite ambulacra may differ from those of other blastozoans.

All diploporites fall into two major groups (Paul 1988); those with extensive ambulacra with a regular structure which, with the sole exception of Estonocystis Jaekel, 1918, have a single facet per ambulacral plate (Fig. 2B), and those without a regular ambulacral structure, whose food grooves lack flooring and cover plates and appear etched out of the underlying thecal plates (Fig. 2A). We propose to call the former the Ambulacralia nov. and the latter, the Anambulacralia nov. The Ambulacralia includes the families Asteroblastidae, Dactylocystidae, Eumorphocystidae, Gomphocystitidae, Mesocystidae and Protocrinitidae. The Anambulacralia includes the families Aristocystitidae, Holocystitidae, Parasphaeronitidae and Sphaeronitidae. Anambulacralians can be traced back to the middle Cambrian genus Lichenoides Barrande, 1846, which also lacks a stem (Ubaghs 1953, 1968), has epithecal food grooves that extend over the theca and lack both flooring and cover plates (Paul 1988, p. 202), and has five radially-positioned circumoral plates forming the mouth frame (Ubaghs 1968).

Recently, Sheffield \& Sumrall (2019a) have evaluated the morphology and relationships of Eumorphocystis and (2019b) have considered the phylogeny of the entire Diploporita. We broadly agree with their interpretation of the anatomy of Eumorphocystis, but they attributed it to an order 'Glyptosphaeritida' (Sheffield \& Sumrall 2019b, fig. 1, p. 741). We also acknowledge that diplopore-like structures occur in the edrioasteroid Thresherodiscus Foerste, 1914 (Sumrall \& Gahn 2003, 2006). Nevertheless, Thresherodiscus is clearly an edrioasteroid not any sort of blastozoan, and each of its 'diplopores' is confined to a separate adambulacral plate (Sumrall \& Gahn 2006, fig. 5.1, p. 504). Such a structure is more similar to the ambulacral plates of echinoids, each of which bears a tube foot. Furthermore, at present it seems likely that genuine diplopores were acquired independently in the Ambulacralia and Anambulacralia and so cannot be used to characterize a monophyletic taxon. However, until the likely sister group of the Ambulacralia within the 'Eocrinoidea' is identified, which is beyond the scope of this study, it is not possible to define the phylogeny of the diploporites fully.

In summary, in the past Glyptosphaerites has been interpreted as the archetype of a major group of diploporites characterized by a definite ambulacral structure (Kesling 1968), whereas it lacks most of the key characters of that taxon. Equally, it bears many of the features that characterize the diploporite family Sphaeronitidae, so its systematic position needs re-evaluating. Secondly, diploporite ambulacra differ from those of other blastozoans, such as the glyptocystitoid rhombiferans. Even those with an organized structure characteristic of the 
axial skeleton bear diplopores, which suggests they might be part of the extraxial not the axial skeleton. So, the purposes of this paper are to attempt to resolve these anomalies.

This paper forms one of a series prepared in anticipation of the proposed revised edition of the Treatise on Invertebrate Paleontology, Part $S$, which will cover the Blastozoa. The papers aim to redescribe to modern standards key genera that are either new (Paul \& GutiérrezMarco 2020), or have been misclassified (Paul 2018) or inaccurately described (Paul \& Toom 2021). The aim is to establish the basic morphological facts before attempting a comprehensive cladistic analysis. To us it seems premature to attempt cladistic analyses of major taxa when the basic morphology of key constituent genera may be misunderstood. The first step here is to establish the detailed morphology of Glyptosphaerites.

\section{METHODS}

Specimens of the type species were examined and photographed. Outlines of ambulacra were drawn with a Wild camera lucida, or directly on suitable photographs. For other species, we have largely relied on literature descriptions.

\section{SYSTEMATIC PALAEONTOLOGY}

Measurements, terminology and repositories. Measurements (in mm) were made directly from specimens using a Kyowa binocular microscope with micrometer eyepiece, or from enlarged photographs with a scale included. The theca of Glyptosphaerites (Fig. 1A) is broadly spherical with a circular, aboral, attachment area opposite the mouth. The pentagonal peristome is covered by a palate of 11 interradial palatal plates, from which five epithecal food grooves radiate over the adoral half of the theca and periodically give rise to small, ambulacral facets. The mouth frame is composed of six circumoral plates (symbol CO), five of which are directly radial and bear the food grooves plus the first ambulacral facet (1-5, Fig. 1A), which is always to the left of the main food groove viewed in the direction of growth. The sixth, here interpreted as perioral plate seven (PO7), lies in the CD interambulacrum of Carpenter $(1884,1891)$ and is associated with the hydropore (H, Fig. 1A). The gonopore (G, Fig. 1A) is associated with plate CO1. In Glyptosphaerites, the mouth and anus (An, Fig. 1A) are separated by several plates, whereas in other sphaeronitid genera PO7 forms part of the border of both mouth and anus. Specimens described here are deposited in the Department of Geology, Tallinn University of Technology, Tallinn,
Estonia (GIT), the Natural History Museum, London (NHMUK) and the Geological Collections of the Natural History Museum, University of Tartu, Estonia (TUG).

\section{Subclass ANAMBULACRALIA nov.}

Diagnosis. Stemless diploporites with an oral frame composed of either or both radial circumorals and interradial periorals; outside the peristome food grooves lie directly on thecal plates and lack floor and cover plates.

\section{Superfamily SPHAERONITOIDA Neumayr, 1889}

Diagnosis. Directly attached anambulacralians with a distinct attachment area; four or five ambulacra and an oral cover of six or eleven interradial palatal plates.

\section{Family SPHAERONITIDAE Neumayr, 1889}

Diagnosis. Sphaeronitoids with an oral frame including five radial circumorals; with diplopores.

Remarks. The Sphaeronitoida includes two families. The Holocystitidae is characterized by pore structures called humatipores, in which several buried tangential canals connect the pair of perpendicular canals and the mouth frame is typically composed of six interradial, perioral plates, two in the posterior (CD) interambulacrum and one each in the other four interambulacra (Fig. 6A). In contrast, the Sphaeronitidae have diplopores in which the pair of perpendicular canals open in a shallow trough, called the peripore (Fig. 7A, B), which was covered by soft tissue in life, and a mouth frame of six circumoral plates, five of which are directly radial and bear the food grooves and first ambulacral facet (Fig. 6B). The Sphaeronitidae is a large family and several subfamilies have been proposed (e.g. Frest 1983; Paul 1997; Frest et al. 2011) as well as the related family Parasphaeronitidae (Bockelie 1984). Revision of the family is beyond the scope of this paper.

\section{Subfamily GLYPTOSPHAERITINAE Bernard, 1895 (nom. transl.)}

[Synonym Diplosphaeroninae Paul, 1997]

Diagnosis. Sphaeronitids with a single food groove leaving each ambulacral orifice; with more than one plate between peristome and periproct; with scattered oval diplopores.

Remarks. Bernard's original family name (as Glyptophaeritinae) can be retained for a subfamily of the Sphaeronitidae characterized by the possession of large thecae, in which the peristome and periproct are separated by three or more plates. In typical sphaeronitines, a single plate, here interpreted as PO7, contributes to both the peristome and periproct borders (7, Fig. 6B). In some 


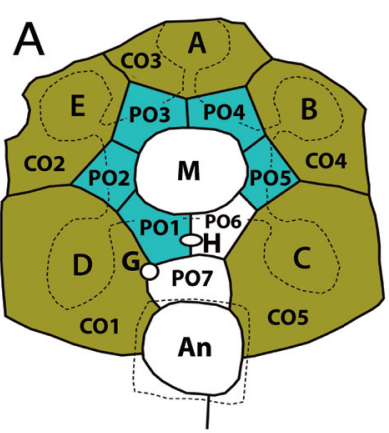

Circumoral plates

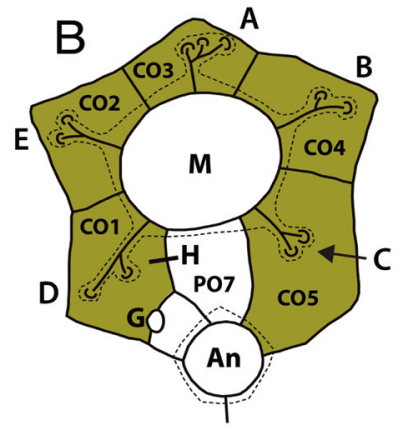

Perioral plates
Fig. 6. Oral areas of (A) the holocystitid Pustulocystis pentax Paul, 1971 and (B) the sphaeronitid Eucystis angelini Regnéll, 1945. In P. pentax, the mouth frame is composed of six perioral plates (PO1-PO6) of which PO1 and PO6 share the hydropore $(\mathrm{H})$. Outside the perioral circlet is the circumoral circlet (CO1$\mathrm{CO} 5)$ which bears large facets for the unknown appendages of the five ambulacra (A-E). The gonopore $(\mathrm{G})$ is shared by plates PO7 and CO1. The anus (An) is separated from the mouth (M) by three plates, PO1, PO6 and PO7. Food grooves lie along the perioral plate sutures and extend to facets centrally on the circumoral plates. In E. angelini (B), the mouth frame is composed of five circumoral plates (CO1-CO5) and PO7, which is the only plate separating the mouth and anus. The gonopore is shared by $\mathrm{CO} 1$ and another plate (traditionally CO7). Food grooves leave the mouth centrally on circumoral plates and in this species branch to multiple small facets for unknown ambulacral appendages confined to the circumoral plates. In life, the mouth was covered by a palate of six interradial plates in both genera. The oral plating of Pustulocystis is almost identical to that of Eucystis with the addition of perioral plates.

species of Eucystis Angelin, 1878, the gonopore plate (originally regarded as CO7) may have common sutures with both $\mathrm{CO} 1$ and $\mathrm{CO} 5$, thus isolating the periproct from plate $\mathrm{PO} 7$, but this is not consistent and requires a revision of Eucystis to establish its significance.

Genera included. Glyptosphaerites Müller, 1854, Archegocystis Jaekel, 1899, Diplosphaeronis Paul, 1973 and possibly Proboscisphaeronis Paul, 1997.

Occurrence. Lower to Upper Ordovician, Europe, Iran. Glyptosphaerites is known from the Tremadocian of the Czech Republic (Prokop \& Petr 1999); the Darriwilian of Sweden, Estonia and the St Petersburg province of Russia (Regnéll 1945), possibly from the Dapingian of Iran (Lefebvre et al. 2005) and the Upper Ordovician (Katian) of Spain ('Proteocystites hispanica Meléndez, 1944', see Colmenar et al. 2015, fig. 21E, F, p. 240). Jaekel (1899, p. 425) recorded G. mariae Jaekel, 1899 from drift deposits in N Germany.
Genus Glyptosphaerites Müller, 1854

Synonyms. Sphaeronites Volborth, 1846 (non Hisinger, 1828); Glyptosphaera Angelin, 1878; Protocrinites Eichwald, 1856, 1860 (non Eichwald, 1840).

Type species. Sphaeronites leuchtenbergi Volborth, 1846, according to Eichwald (1860, p. 620), from the Middle Ordovician, Vaginatenkalk in the neighbourhood of St Petersburg, Russia, which corresponds to the Kunda Regional Stage (Darriwilian). Holotype PMSPU 7-1 in the collection of the Paleontological Museum of St Petersburg State University. Estonian specimens are from the Middle Ordovician (Darriwilian) sediments, according to collection labels, from the Aseri and Uhaku regional stages.

Other species. Glyptosphaerites suecica Angelin, 1878, from the 'Lower Chasmops Limestone' of Dalarna, Sweden, which corresponds to the Lower Kullsberg Limestone and is of Upper Sandbian to Lower Katian age (Kröger \& Aubrechtová 2019). Regnéll (1945, p. 157) doubted its validity, but accepted it was distinctly younger than G. leuchtenbergi. Glyptosphaerites ferrigena Barrande, 1887 from the Tremadocian Trenice and Mílina formations, Czech Republic (Mergl \& Prokop 2006), G. mariae Jaekel, 1899 from drift boulders of supposed Ordovician age in North Germany, G. hispanica (Meléndez, 1944) from the Upper Ordovician, Cystoid Limestone (Katian) of Aragon, Spain (Alvaró et al. 2015). An unnamed species that lacks clear evidence of the extensive food grooves has been reported from Iran (Lefebvre et al. 2005, pl. 1, figs 10-14).

Stratigraphic distribution. Early to Late Ordovician (Tremadocian-Katian).

\section{Figured material. GIT, NHMUK, TUG.}

Diagnosis. Glyptosphaeritines having large globular theca with five ambulacra with extensive food grooves that reach the ambitus and branch repeatedly.

Description. Glyptosphaerites has a large (up to $50 \mathrm{~mm}$ diameter), globular theca (Fig. 8A), with a circular attachment area aborally composed of seven 'basal' plates (Fig. 8B), opposite a small, pentagonal mouth, from which five narrow, branched food grooves extend over the theca at least to the ambitus (Fig. 8C, D, G). The theca is composed of many small, smooth plates, which are added during growth and bear small, oval diplopores (Figs 2A, $8 \mathrm{E})$. The diplopores are regularly oval, reach about 0.6 by $0.35 \mathrm{~mm}$ externally, with very narrow raised rims and perpendicular canals reaching $0.12 \mathrm{~mm}$ diameter (Figs 2A, 8E). The long axis of the oval peripore is perpendicular to the nearest plate suture (Fig. 8E). 

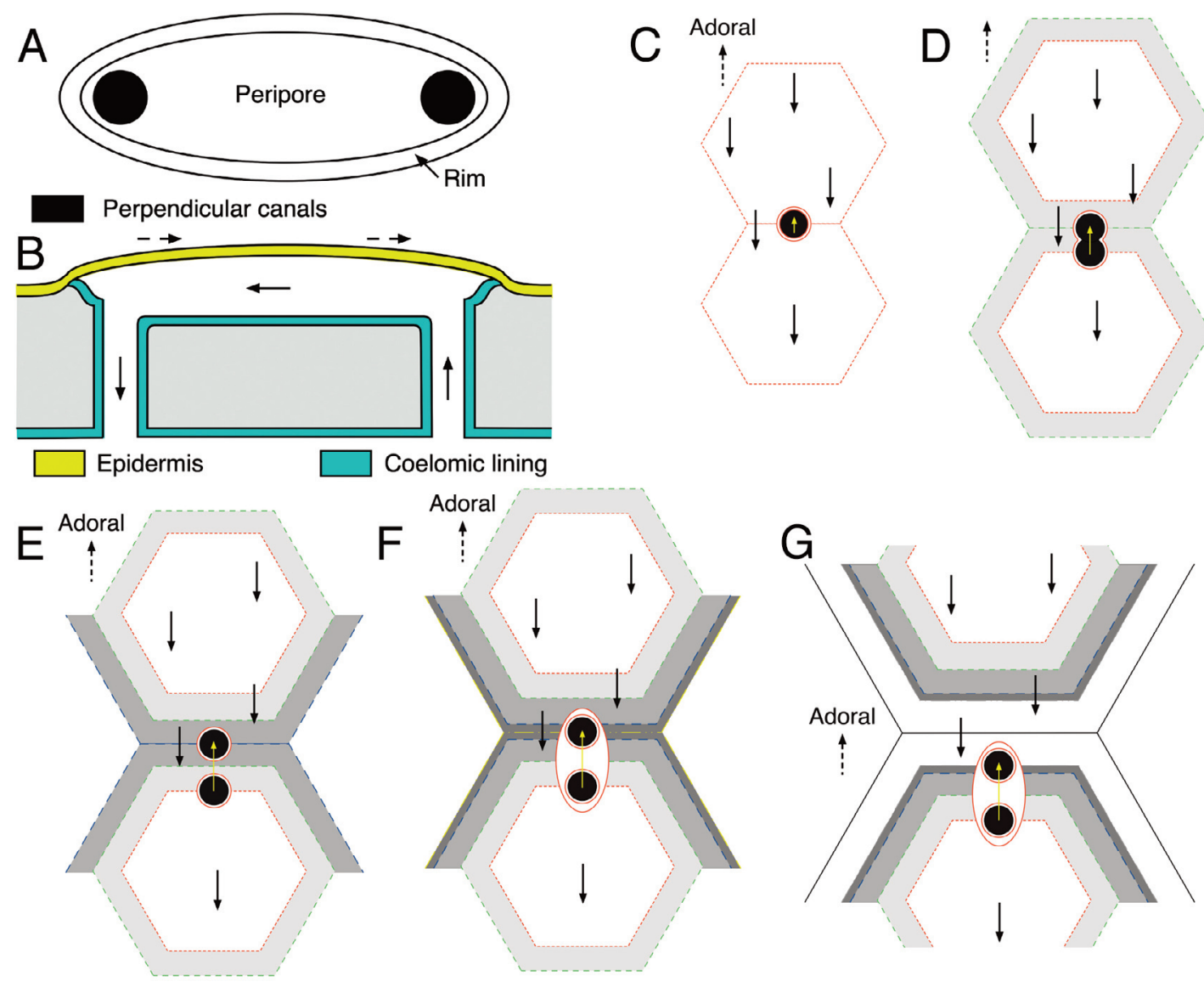

Fig. 7. Morphology (A, B) and growth (C-G) of diplopores in Glyptosphaerites leuchtenbergi (Volborth, 1846). A, plan view of a diplopore showing two perpendicular canals (black) opening into the peripore and surrounded by a raised rim. B, cross-section through the perpendicular canals and peripore with soft tissue cover restored showing one way circulation of coelomic fluids (solid arrows) and supposed external counter current (broken arrows). C-G, growth of a diplopore in G. leuchtenbergi and supposed external surface current flowing aborally (solid arrows). C, earliest stage. A single, epispire-like, perpendicular canal on the plate suture. An internal counter current (pale arrow) rises up the aboral plate and descends beside the adoral plate. $\mathbf{D}$, first growth increment (pale grey). A second perpendicular canal forms at the plate suture. E, further growth (darker grey increment). The two perpendicular canals separate, but the adoral canal remains on the suture. F, the two perpendicular canals reach their final separation and a peripore develops. G, the entire diplopore is incorporated into the aboral plate. Repetition of this process produces the characteristic distribution of diplopores in G. leuchtenbergi where most diplopores occur adorally in thecal plates.

The mouth frame is composed of six plates, five radial circumorals and a sixth (PO7) in the posterior (CD) interambulacrum (Fig. 1A). In TUG 1589-98, the peristome is 5.0 by $2.86 \mathrm{~mm}$ in a theca $41 \mathrm{~mm}$ in diameter. In the type species, the peristome is covered by a palate of eleven immovable plates (Figs 5, 8C), three in the posterior CD interambulacrum and two each in the other four (Fig. 5). Five narrow food grooves, up to $0.2 \mathrm{~mm}$ wide, radiate from the corners of the peristome (Fig. 8C, D, G), each giving rise to a small ambulacral facet to the left (as viewed in growth direction) within the circumoral plates, although the first facet is undeveloped in ambulacrum A of TUG 1727-27 (Figs 5, 8C). Subsequent facets occur sporadically on either side of the main food groove irregularly and bear no relationship to the plates beneath
(Figs 2A, 3, 4). Individual thecal plates may bear part of the food groove, with or without a facet, or more than one facet. The only broad generalization that can be made about the food grooves is that side branches to the left are short and terminate immediately in a facet, whereas those to the right are generally long (Figs 3, 4, 8F). Facets are small, usually $1.0 \mathrm{~mm}$ across at most, circular, and bear two lateral muscle or ligament pits (Fig. 2A). They are raised slightly above the surface of the thecal plates. The food grooves are also provided with very narrow raised borders (Figs 2A, 5A, 8C, D, F, G), but there is no trace of both flooring and cover plates. The edges of the food groove entirely lack the ledge that supports ambulacral cover plates in ambulacralian diploporites (Fig. 2B top). 

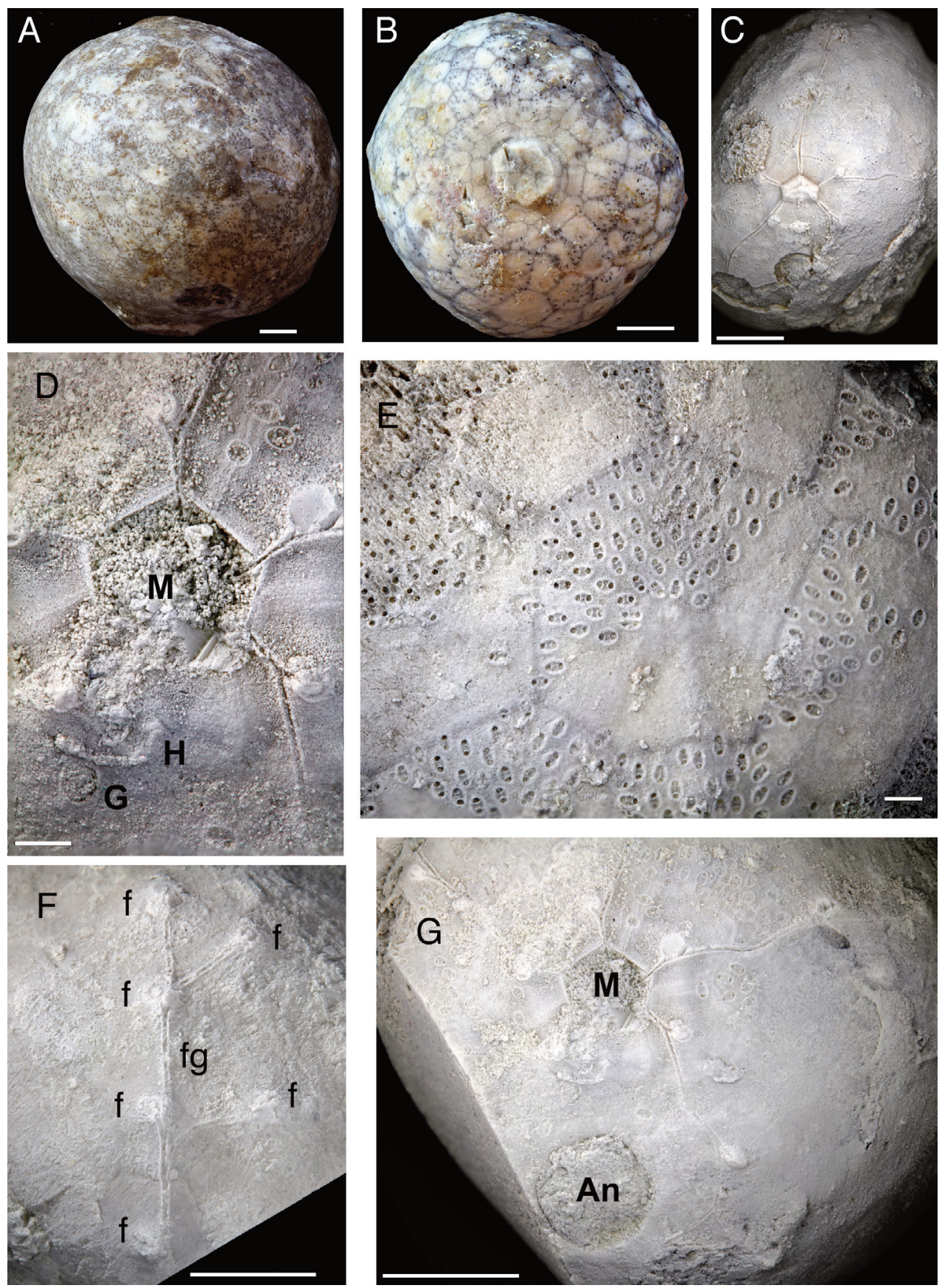

Fig. 8. Photographs of Glyptosphaerites leuchtenbergi (Volborth, 1846). A, lateral view of TUG 1727-392 (Estonia; Kandle Formation, Aseri Regional Stage, Darriwilian), showing thecal outline. B, basal view of TUG 1727-28 (Vanaküla Quarry in Olgina, Estonia; Kandle Formation, Aseri Regional Stage, Darriwilian), showing the attachment area (centre), thecal plates and diplopores. C, oral area of TUG 1727-27 (Valaste, Estonia; Kandle Formation, Aseri Regional Stage, Darriwilian), showing the palate covering the pentagonal mouth above the larger, rounded periproct (below) and five radiating food grooves. Ambulacrum A (above) lacks the first facet in this specimen. D, G, oral view of GIT 540-63 (Lopatovo 8 drill core, Pskov Region, Russia; Uhaku Regional Stage, Darriwilian). D, close-up showing the mouth $(\mathrm{M})$, gonopore $(\mathrm{G})$ and hydropore $(\mathrm{H})$. G, general view showing the mouth $(\mathrm{M})$ and anus (An). All five ambulacra have the first facet on the circumoral plates. E, close-up of thecal surface of TUG 1727-66 (Vanaküla Quarry in Olgina, Estonia; Kandle Formation, Aseri Regional Stage, Darriwilian), showing uneven distribution of diplopores within plates and orientation of diplopore axes perpendicular to plate sutures. The diplopores are predominantly in the upper parts of each plate, but exceptions do occur (far right). F, detail of a single food groove in GIT 540-61 showing that left facets (f) are close to the main food groove (fg), whereas right facets are terminal to lengthy side branches. Cf. Figs 2A, 8. A, B, uncoated; $\mathbf{C}-\mathbf{G}$, whitened with ammonium chloride. Scale bars $=5 \mathrm{~mm}(\mathrm{~A}-\mathrm{C}, \mathrm{F}, \mathrm{G})$ and $1 \mathrm{~mm}(\mathrm{D}, \mathrm{E})$. 
The periproct (An, Fig. 8G) is slightly larger than the peristome, rounded polygonal in outline and the two are separated from each other by about one and a half times their largest dimension (Fig. 8C, G). It was probably covered by a simple pyramid of periproctal plates, but none has been preserved on specimens seen by us. A slitlike hydropore (H, Figs 1A, 5C, 8D) occurs in the $\mathrm{CD}$ interambulacrum closer to the $\mathrm{D}$ ambulacrum and slightly above a circular gonopore (G, Figs 1A, 8D).
There is a planar, subcircular attachment area $6 \mathrm{~mm}$ across in TUG 1727-28 and 5.4 mm across in TUG 172765. It is composed of seven 'basal' plates in both examples (Fig. 9). Plates other than the circumorals and basals are of two or three generations (Figs 8B, 9A), rarely exceed $5 \mathrm{~mm}$ across and are generally smooth externally. All plates except some of the basalmost bear diplopores (Fig. 9A), which are usually unevenly distributed within the plates (Figs 8E, 10).
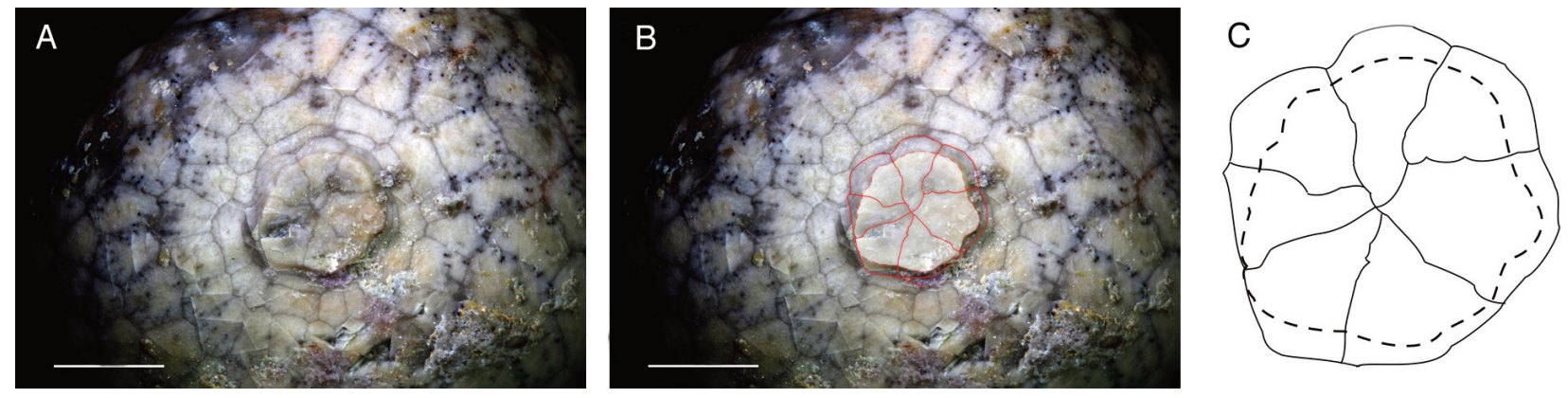

Fig. 9. Attachment area of Glyptosphaerites leuchtenbergi (Volborth, 1846) TUG 1727-28 (Vanaküla Quarry in Olgina, Estonia; Kandle Formation, Aseri Regional Stage, Darriwilian). A, detail of the aboral theca showing a flat central attachment area. B, the same with the outline of the attachment area and plate sutures highlighted. C, interpretation of the attachment area (broken line) and seven 'basal' plates (solid lines). Scale bars $=5 \mathrm{~mm}$.
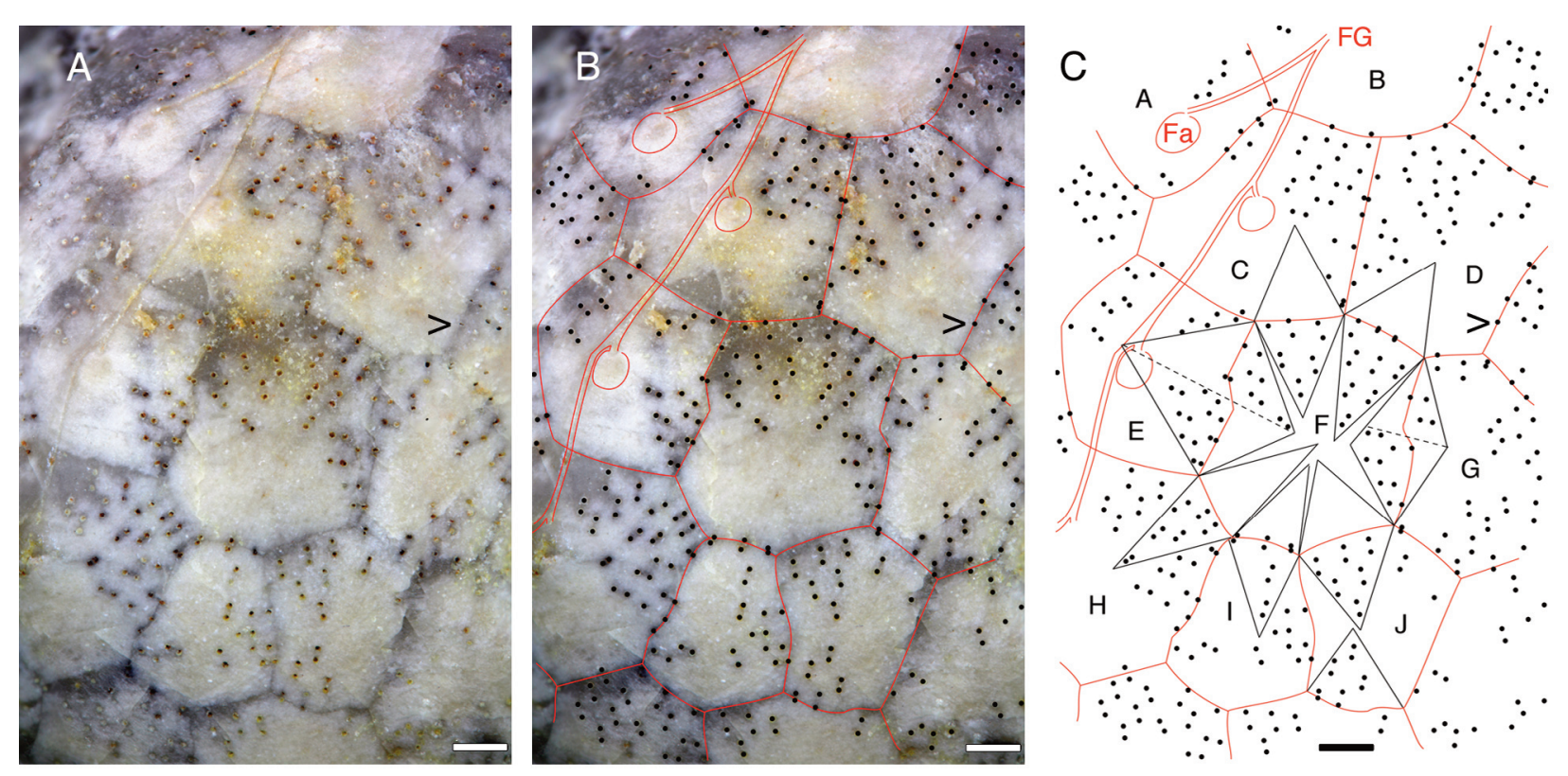

Fig. 10. Diplopores in Glyptosphaerites leuchtenbergi (Volborth, 1846), TUG 1727-28 (Vanaküla Quarry in Olgina, Estonia; Kandle Formation, Aseri Regional Stage, Darriwilian). A, part of the theca showing plates, diplopores and food groove with facets. B, the same with plate outlines, diplopores and food grooves highlighted. C, details of the diplopores and plates. A-J, selected individual plates; Fa, ambulacral facet; FG, food groove; > indicates an isolated perpendicular canal on the suture of plate D. In plate F, the outlines of the triangular sectors within which the diplopores developed are indicated across all plate sutures. In the top two and bottom three sectors, the diplopores are almost exclusively within the adoral parts of the plates involved with no diplopores at all in the lower part of plates C, D and scarcely any in F. In contrast, in the lateral two sectors, almost all the perpendicular canals are within plates $\mathrm{F}$ and $\mathrm{G}$ above the dashed lines and all within plates $\mathrm{E}$ and $\mathrm{F}$ below the dashed lines. This demonstrates preferential incorporation of diplopores into one or other side of a plate suture. Scale bars $=1 \mathrm{~mm}$. 
Diplopores open on the external surface in oval peripores, which are about $0.5-0.65 \mathrm{~mm}$ long by $0.35-$ $0.45 \mathrm{~mm}$ wide and with weak peripore rims (Figs 2A, 6E). Perpendicular canals are $0.1-0.125 \mathrm{~mm}$ in diameter and separated by up to $0.2 \mathrm{~mm}$. Most diplopores are orientated so the axis joining the two perpendicular canals is perpendicular to the nearest plate suture (Figs 6E, 10, 11). Diplopores do cross plate sutures, but relatively rarely. Perpendicular canals occur quite commonly exactly on plate sutures (Fig. 2A left; Fig. 10). They pass straight through the thecal plates (Fig. 12A). Food grooves sometimes appear to have grown over pre-existing diplopores (Fig. 10B).

Remarks. Glyptosphaerites has an oral frame composed of five radial circumoral plates and a sixth interradial oral in the posterior, CD interradius. Narrow food grooves, which entirely lack floor and cover plates, leave the pentagonal peristome centrally in the circumoral plates. Food grooves spread over the theca at least to the ambitus, periodically giving rise to further small lateral facets for erect feeding structures which are never preserved, but were probably biserial brachioles. There is no consistent relationship between the food grooves or facets and the underlying thecal plates, except that in all but one example seen (TUG 1727-27, Fig. 5) the first ambulacral facets are always left of the main food groove on the circumoral plates. Thecal plates may have one or more food grooves or lack food grooves entirely; they may have one or more facet, sometimes two facets are connected to food grooves of two different ambulacra.

Thus, the axial skeleton of Glyptosphaerites consists of several isolated unknown feeding structures, plus possibly the circumoral plates. Circumoral plates always contain diplopores. In life, the peristome was covered by a palate of 11 immovable palatal plates, three in the posterior, $\mathrm{CD}$ interambulacrum and two in the other interambulacra. Food travelled down the food grooves, which entered the peristome through small ambulacral orifices, and continued to the inner margin of the peristome.

A hydropore, which is slit-like in TUG 1727-65 (Fig. 8D), but usually depicted as a complex series of slits (e.g. Regnéll 1945, fig. 18, p. 155), and a circular gonopore occur (Fig. $8 \mathrm{D}$ ) in the $\mathrm{CD}$ interambulacrum, to
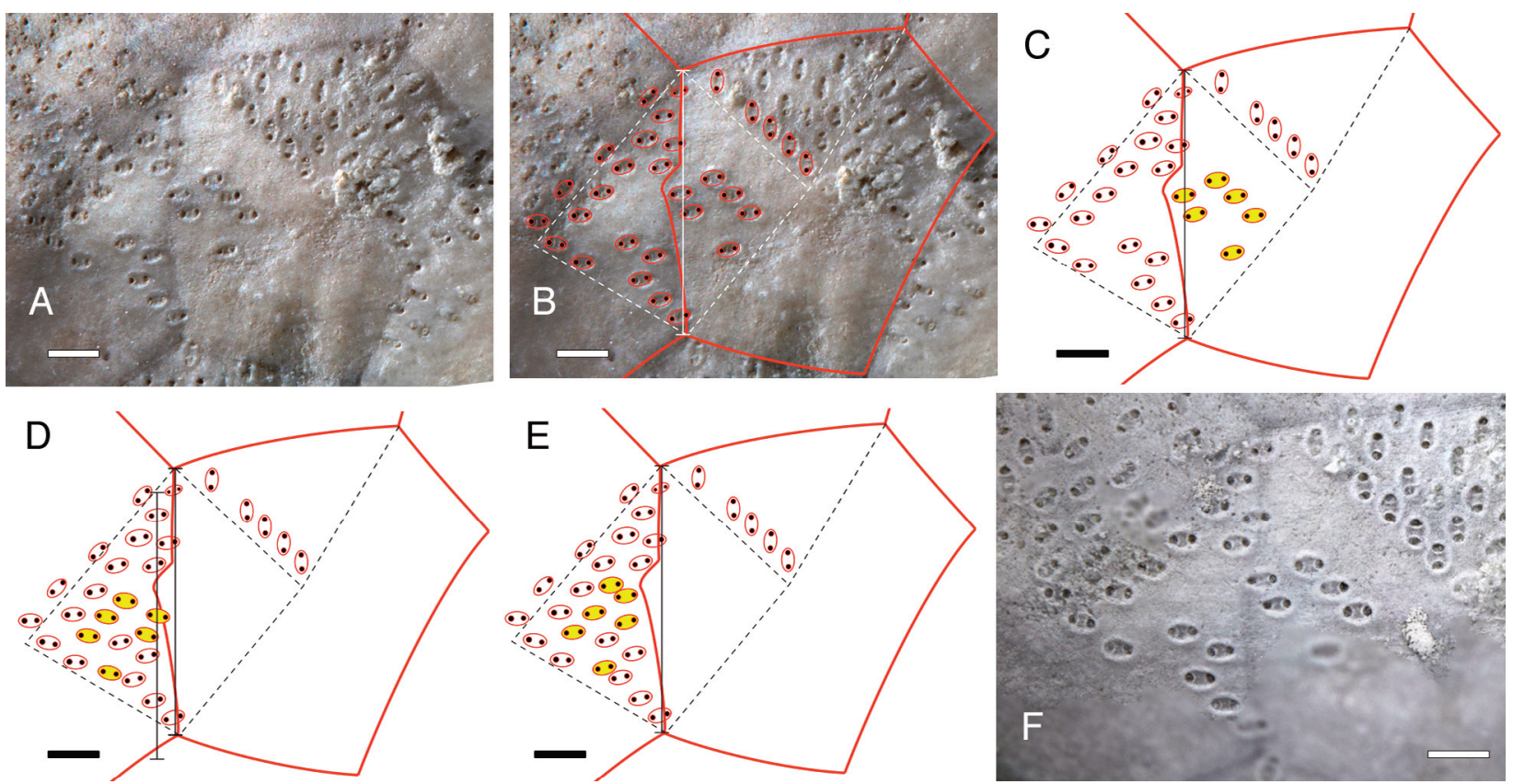

Fig. 11. Diplopore development in Glyptosphaerites leuchtenbergi (Volborth, 1846). A, detail of some diplopores in TUG $1727-66$ (Vanaküla Quarry in Olgina, Estonia; Kandle Formation, Aseri Regional Stage, Darriwilian), uncoated. B, the same with the outline of plate sutures (solid lines), three triangular growth sectors (broken lines) and selected diplopores highlighted. C, the interpretation showing six highlighted diplopores in the right-hand plate. We suggest that these six diplopores arose initially in the spaces between the diplopores in the left-hand plate but became incorporated within the right-hand plate. $\mathbf{D}$, an attempt to restore the six highlighted diplopores to their mirror positions by rotating them about the vertical solid line and then adjusting their positions to fit the spaces in the left-hand plate. The two vertical grey lines indicate the amount of adjustment necessary. $\mathbf{E}$, an alternative means of repositioning the six highlighted diplopores by moving each individually across the suture an equivalent distance in the direction of each diplopore axis. This gives a better result. F, a lightly coated photograph of the same area of TUG 1727-66 showing faint 'ghosts' of diplopores in the gaps between the diplopores in the left-hand plate. Adoral is above in all diagrams. Scale bars $=1 \mathrm{~mm}$. 

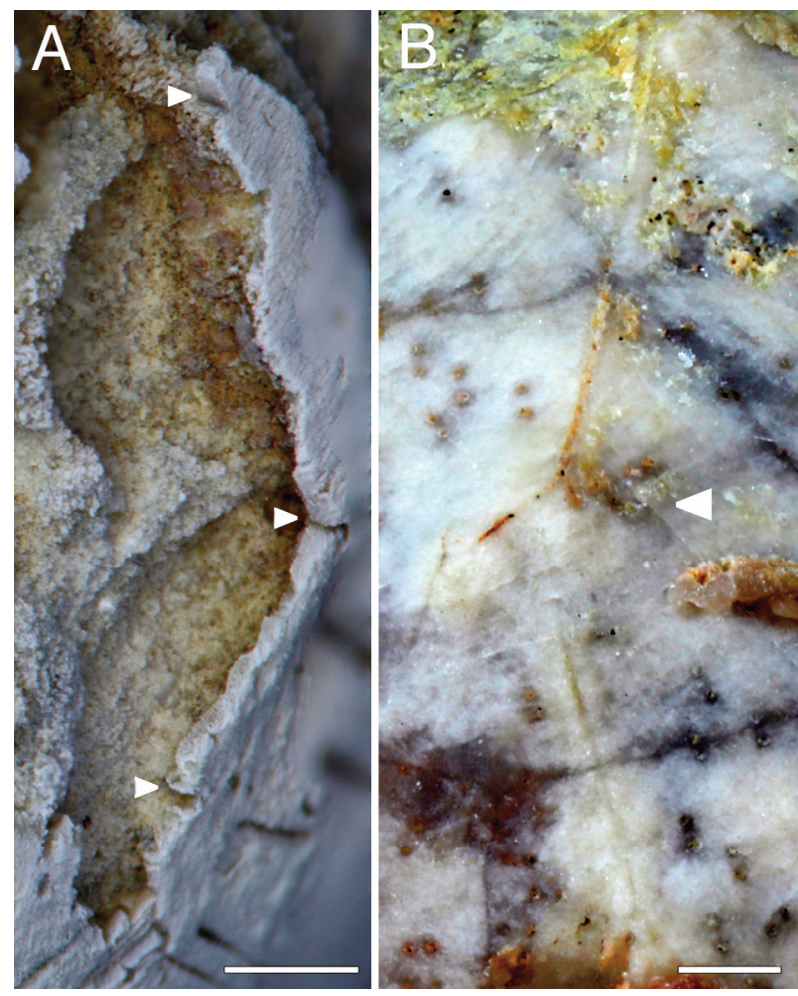

Fig. 12. Photos of Glyptosphaerites leuchtenbergi (Volborth, 1846). A, detail of TUG 1727-65 (Vanaküla Quarry in Olgina, Estonia; Kandle Formation, Aseri Regional Stage, Darriwilian), showing the weathered part of the theca with three perpendicular canals (white arrows) passing straight through. B, detail of one food groove in TUG 1727-28 (Vanaküla Quarry in Olgina, Estonia; Kandle Formation, Aseri Regional Stage, Darriwilian), showing an ambulacral facet overgrowing a diplopore (arrowed). A, whitened with ammonium chloride, $\mathbf{B}$, uncoated to reveal diplopores. Scale bars $=1 \mathrm{~mm}$.

the left of the oro-anal axis. A polygonal periproct occurs below the gonopore and hydropore and is usually larger than the mouth. It is surrounded by a ledge for the insertion of anal cover plates, but none has been preserved. Aborally, was a roughly circular attachment area composed of seven 'basal' plates (Fig. 9). Volborth (1846, pl. 10, figs 2,6) illustrated an example with a stem. We believe this resulted from an example that grew on a crinoid stem. Already Eichwald (1860, p. 620) noted that he had an example with a short, conical stem covered in diplopores, quite unlike the one figured by Volborth.

All the above characters are typical of anambulacralian diploporites. Radially-positioned circumoral plates make the mouth frame in the family Sphaeronitidae. A palate of six immovable plates, with small peripheral ambulacral orifices, from which epithecal food grooves emerge, is characteristic of the families Holocystitidae and Sphaeronitidae. The gonopore and hydropore lie between the mouth and anus on or to the left of the oro-anal line in the Aristocystitidae, Sphaeronitidae and Holocystitidae. The sphaeronitid genera Archegocystis Jaekel, 1899, Haplosphaeronis Jaekel, 1926 and Sphaeronites Hisinger, 1828, and the aristocystitid genus Aristocystites Barrande, 1887 are known to have had seven 'basal' plates. The attachment structures attributed to the holocystitid genus Paulicystis Frest \& Strimple, in Frest et al. (2011), have seven basal plates surrounding a centrodorsal (Thomka \& Brett 2014, fig. 4, p. 182).

In contrast, ambulacralian diploporites have an oral frame composed of six, interradial perioral plates, which do not bear facets. Food grooves with biserial cover plates leave the peristome along the sutures between the periorals. If there are extensive ambulacra, they are composed of regularly alternating ambulacral plates that form part of the thecal wall and each of which gives rise to a single erect feeding structure; either a biserial brachiole or a uniserial pinnule. In all families except the Gomphocystitidae, there is a holomeric stem, at least in juveniles. Thus, we conclude the genus Glyptosphaerites is more closely related to anambulacralians than ambulacralians and specifically belongs in the family Sphaeronitidae

\section{ORIGIN OF DIPLOPORES}

\section{Diplopores of Glyptosphaerites}

Glyptosphaerites has a theca composed of numerous plates that were added during growth, but do not show the different generations clearly. All thecal plates, except a few near the base of the theca (Fig. 9A), bear small, oval diplopores. The axes connecting the two perpendicular canals are almost exclusively arranged perpendicular to the nearest plate suture (Jaekel 1899, fig. 26, p. 118; fig. 81, p. 358; Fig. 10 herein). Another unusual feature of Glyptosphaerites diplopores is their uneven distribution within plates (Figs 10, 11). Regnéll (1945, pl. 10, fig. 1) illustrated a Swedish specimen with diplopores concentrated in the upper parts of most plates. Close examination of Estonian specimens shows how the asymmetrical distribution of Glyptosphaerites diplopores came about (Fig. 7).

\section{Diplopore growth}

The diplopores consist of a pair of perpendicular canals opening externally in a shallow, oval pit called a peripore (Fig. 7A, B). In life, coelomic fluids flowed up one perpendicular canal, expired $\mathrm{CO}_{2}$ and gained $\mathrm{O}_{2}$ through the peripore cover, and descended down the other perpendicular canal (Fig. 7B). As the fluids flowing through 
the diplopore were coelomic fluids, there was no need to modify the canals to prevent entry of foreign particles, as there is with canals through which sea water flowed. Thus, in diplopores we have no evidence of the direction of flow. Nevertheless, we may make some inferences. In very small juveniles with thin plates, respiratory gas exchange would have taken place through the thecal plates. The facts that the attachment area is planar and directly opposite the mouth suggest that in life G. leuchtenbergi attached to a horizontal, planar surface with the mouth uppermost in the theca. External ciliary currents probably developed flowing down aborally to clean the thecal surface. So, for efficient respiratory gas exchange, internal ciliary currents flowed in the opposite direction (adorally). Thus, in a diplopore that started to develop on a horizontal plate suture, one might expect a pre-existing internal ciliary current flowing adorally (Fig. 7C, pale arrow). As the plates grew the single perpendicular canal became enveloped by one of the plates and the second perpendicular canal developed (Fig. 7D). Further plate growth enclosed the first perpendicular canal further from the suture until the two perpendicular canals reached their final separation (Fig. 7E, F). Eventually, both perpendicular canals and the peripore became incorporated into one plate (Fig. 7G). In Fig. 7, the mouth lay at the top of the diagrams, external currents (solid black arrows) flowed aborally, and hence internal currents of coelomic fluids (pale arrows) flowed adorally. Thus, even when only one perpendicular canal had developed (Fig. 7C), ciliary currents emerged from inside the theca in the aboral plate and descended back into the theca down the edge of the adoral plate. If so, when two canals developed, the aboral canal would have held ascending currents saturated with $\mathrm{CO}_{2}$ and the sutural canal would have held descending currents saturated with $\mathrm{O}_{2}$. So, the trigger that
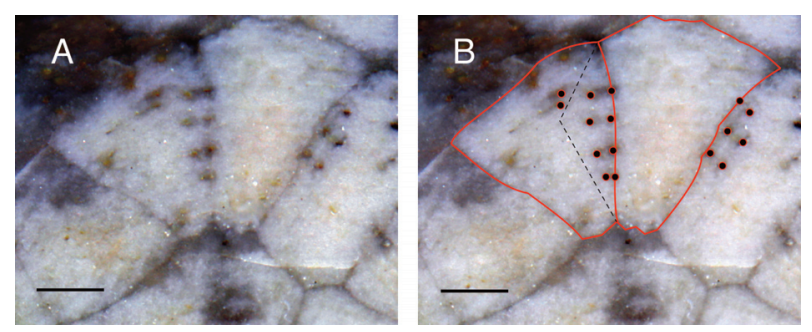

Fig. 13. A, detail of plates in Glyptosphaerites leuchtenbergi (Volborth, 1846), TUG 1727-28 (Vanaküla Quarry in Olgina, Estonia; Kandle Formation, Aseri Regional Stage, Darriwilian), uncoated, showing four diplopores each with one perpendicular canal on a plate suture (centre). The separation of the perpendicular canals is proportional to the width, and therefore the rate of growth, of the left plate which encloses the diplopores. B, plate sutures (solid lines) and growth sector (dashed lines) of the left plate. Note that none of the diplopores shown became incorporated into the central plate. Scale bars $=1 \mathrm{~mm}$. decided into which plate the diplopore became incorporated was probably the internal current direction.

During normal plate growth of recent echinoids, the outer part of the plate, composed of galleried stereom (Smith 1980), forms the complete thickness of the plate at the suture. This is also true of fossil diploporites (Paul 1971, fig. 2e, f, p. 10). In echinoids, the galleries are perpendicular to the sutures and filled with collagen fibres that bind round the calcite trabeculae of the stereom to hold the plates together. When a perpendicular canal penetrated the suture, it interrupted the normal galleried stereom, which was replaced by labyrinthic stereom. The labyrinthic stereom developed in both plates as the diplopore grew (see Paul 1971, fig. 8, p. 22). So, when the diplopore became incorporated into one plate, a 'ghost' of labyrinthic stereom was incorporated into the other plate. Paul (1971, fig. 2a, b, p. 10) illustrated several examples of this, but misinterpreted them as failed diplopores the perpendicular canals of which had been sealed with stereom. We now think these oval areas of galleried stereom represent diplopores that became incorporated into the opposite plate. Figure $11 \mathrm{~F}$ illustrates a lightly coated version of TUG 1727-66 in which the 'ghosts' of some of the diplopores can still be seen. This also tends to confirm the interpretation of diplopore growth proposed here.

The separation of perpendicular canals is proportional to the rate of plate growth in TUG 1727-28 (Fig. 13). In one plate, four diplopores still have one perpendicular canal on or very close to the plate suture, but the diplopores with the most widely separated perpendicular canals occur in the widest part of the plate where plate growth was most rapid. This pattern is predicted by the model of diplopore growth shown in Fig. 7D-G. This shows that the separation of perpendicular canals was determined by the rate of plate growth up to the maximum separation when the diplopores became fully enclosed within a plate.

\section{Diplopore distribution}

A further consequence of this model of diplopore growth is that the axis of any diplopore, which connects the two perpendicular canals, would be perpendicular to the plate suture on which the diplopore developed, because plate growth is perpendicular to plate sutures (Paul 1971, figs 2a, 3a, pp. 10-12; Sprinkle 1973, fig. 11b, p. 28). Paul (1972, fig. 12, p. 15; 1973, fig. 21, p. 33) and Bockelie (1984, fig. 14, p. 21) made the same inference about internal currents in the diplopores of another sphaeronitid, Haplosphaeronis Jaekel, 1926, the diplopores of which are predominantly orientated in an oral-aboral direction and asymmetrical. In Haplosphaeronis, the asymmetry reverses between the oral and basal circlets and so the external currents were also inferred to reverse. In 
Glyptosphaerites, the external currents apparently flowed down the theca from the mouth to the aboral attachment area, judging by the concentration of diplopores in the adoral parts of even the aboral plates (Fig. 9A).

The examination of examples of $G$. leuchtenbergi confirms the interpretations proposed above (Figs 8E, 10A, 11A). Occasional single canals occur on plate sutures (e.g. Fig. 10C, >). In plate F (Fig. 10C), the growth sectors are indicated by solid black lines. Across the C:F, D:F, F:H, F:I and F:J sutures, virtually all the diplopores are in the aboral sector; that is in the adoral parts of plates F, H, I and J. These sutures are more or less perpendicular to the oral-aboral axis, as indicated by the food grooves (FG, Fig. 10C). However, the two lateral sutures (E:F and $\mathrm{F}: \mathrm{G})$ show a curious phenomenon in which the diplopores in the adoral parts have become incorporated into the right-hand plate, whereas those in the aboral parts (below the dashed lines) are exclusively in the left-hand plates. Thus, all the diplopores that grew in an orientation that benefitted from an internal current flowing adorally became incorporated into the adoral parts of the lower plate. In contrast, diplopores that developed across a plate suture where an adoral internal current was not of particular benefit, show no preference as to which plate they became enclosed within, but once they started to become enclosed in one plate, adjacent new diplopores often became enclosed within the same plate. This could be explained by the adoral and aboral parts of sutures $E: F$ and $F: G$ adopting one or other current direction for the first diplopore to develop and maintaining it thereafter.

Jaekel (1899, p. 118) noted that the diplopores of G. mariae were often developed in a pattern of isosceles triangles. Figure 10 shows a similar pattern in G. leuchtenbergi. The diplopores across the F:J suture are disposed with one near the plate centre, then two on either side of the first and nearer the suture, then three interpolated between the second pair and adjacent to the suture. As the plate grew new diplopores were added regularly and symmetrically. The development of diplopores was not always so regular. A similar pattern of six diplopores disposed in a 1, 2, 3 arrangement is observed in the lower suture of plate J (Fig. 10), but five of the diplopores have been incorporated into the aboral half of plate $\mathrm{J}$, and the sixth occurs below the suture in the adoral half of the plate below. All of these various patterns show that only half the available surface area of the thecal plates bore diplopores in G. leuchtenbergi. The diplopores that developed on a particular plate suture were preferentially, but not exclusively, incorporated into only one of the adjacent plates. When occasionally a diplopore was incorporated into the other plate, it left a gap in the triangular pattern of diplopores that developed in the plate receiving most of the pore structures (Fig. 11).
Other diploporites show that diplopores were incorporated into both plates adjacent to all sutures. These often have densely developed diplopores as in the aristocystitid Oretanocalix, but a similar pattern occurs in the sphaeronitid Archegocystis (Paul 1971, fig. 2, p. 10). Both genera have diplopores with axes perpendicular to plate sutures. In contrast, the diplopores in the adambulacral plates of Protocrinites (Fig. 2B) and Estonocystis Jaekel, 1918 curve around the brachiole facets and must have been added only at the adoral and aboral sutures of the adambulacral plates. The conclusion that diplopores were added to plates in different ways in different diploporite genera and families seems inescapable.

\section{Variation in diplopores}

The perpendicular canals of G. leuchtenbergi passed straight through the plates (Fig. 12A). In contrast, Mergl \& Prokop (2006, fig. 6, p. 9) showed that the Czech Tremadocian species G. ferrigena (Barrande, 1887) has a single large opening to its diplopores in the internal plate surfaces, but a pair of narrow perpendicular canals open in an oval peripore on the external plate surfaces. Mergl \& Prokop (2006, p. 8) interpreted the diplopores to be formed by single Y-shaped canals as they passed through the thecal wall. Further, they suggested the single canals were distributed on plate sutures, such that the external peripores straddled the suture with one perpendicular canal in each plate. We have not been able to examine specimens of $G$. ferrigena and can neither confirm nor refute Mergl and Prokop's interpretation. Nevertheless, we have seen no evidence to support the presence of Y-shaped diplopores in any Estonian specimens of Glyptosphaerites.

\section{Diplopores and the EAT}

The initiation of diplopores on plate sutures described above and their incorporation into one adjacent thecal plate explains their presence in ambulacral plates. Although ambulacral plates are axial and should lack pore structures, for functional efficiency in gas exchange, diplopores would be preferentially incorporated into plates where external currents existed. Ambulacral plates bore brachioles that produced ciliary currents or modified external currents during rheophilic feeding. This probably explains the close association of diplopores and brachiole facets in the Protocrinitidae and, especially, the Dactylocystidae.

Acknowledgements. We are grateful to Gennadi Baranov (Department of Geology, Tallinn University of Technology) for patient digital photography of the specimens without which the paper would have been impossible. We thank Mare Isakar and 
Tim Ewin for access to the geological collections of the University of Tartu, Estonia, and the Natural History Museum, London, respectively. Detailed reviews by J. Sprinkle and the two anonymous reviewers improved the original manuscript considerably. The publication costs of this article were covered by the Estonian Academy of Sciences.

\section{SYSTEMATIC APPENDIX}

\section{Subclass AMBULACRALIA nov.}

Diagnosis. Diploporites with an oral frame composed of interradial periorals; with mural ambulacra composed of biserial, alternate flooring plates each of which bears a facet for a single uniserial or biserial feeding appendage.

Constituent families. Protocrinitidae, Dactylocystidae, Eumorphocystidae, Gomphocystitidae, Asteroblastidae, Mesocystidae.

Remarks. All genera except the gomphocystitids have a functional stem, at least as juveniles; gomphocystitids were directly attached with the attachment area uncalcified (Bockelie 1979). All families except the Gomphocystitidae lack ambulacral facets on perioral plates. Gomphocystitids have spiral ambulacra with facets on the outside of the spiral only (Bockelie 1979; Paul 1984). Thus, their ambulacra are uniserial, but still form part of the thecal wall, i.e., they are mural ambulacra. The protocrinitid genus Estonocystis Jaekel, 1918 has more than one facet per ambulacral plate (Paul \& Hotchkiss 2020, fig. 9, p. 1098), but is otherwise identical to Protocrinites Eichwald, 1840. Eumorphocystis Branson \& Peck, 1940 has initially mural ambulacra that conform to the definition above, but then they develop erect, pinnate 'arms' with triserial axes and alternating biserial brachioles (Parsley 1982; Sheffield \& Sumrall 2019a; Guensburg et al. 2021).

\section{REFERENCES}

Alvaró, J. J., Gutiérrez-Marco, J. C. \& Zamora, S. 2015. Early Paleozoic faunas from the Luna Valley. In Progress in Echinoderm Palaeobiology (Zamora, S. \& Rábano, I., eds), Cuardenos del Museo Geominero, 19, 249-260.

Angelin, N. P. 1878. Iconographia Crinoideorum in stratis Sueciae Siluricis fossilium. Holmiae, Stockholm, iv + 62 pp.

Barrande, J. 1846. Notice préliminaire sur le Systême Silurien et les trilobites de Bohême. Hirshfeld, Leipzig, vi $+97 \mathrm{pp}$.

Barrande, J. 1887. Systême Silurien du centre de la Bohême. Premier Partie: Recherches paléontologiques. Vol. 7, Classe des Échinodermes. Ordre des Cystidés. W. Waagen, Prague, $\mathrm{xix}+233 \mathrm{pp}$.

Bernard, F. 1893-1895. Eléments de Paléontologie. J.-B. Ballière et Fils, Paris, viii +1168 pp.
Bockelie, J. F. 1979. Celticystis n. gen., a gomphocystitid cystoid from the Silurian of Sweden. Geologiska Föreningens $i$ Stockholm Förhandlingar, 101, 157-166.

Bockelie, J. F. 1984. The Diploporita of the Oslo region, Norway. Palaeontology, 27, 1-68.

Branson, E. B. \& Peck, R. E. 1940. A new cystoid from the Ordovician of Oklahoma. Journal of Paleontology, 14, 89-92.

Carpenter, P. H. 1884. Report upon the Crinoidea collected during the voyage of HMS Challenger during the years 1873-76, part 1. General morphology with descriptions of the stalked crinoids. Reports of the Scientific Results of the Voyage of HMS Challenger, Zoology, 11, 1-442.

Carpenter, P. H. 1891. On certain points of the morphology of the Cystidea. Journal of the Linnean Society (Zoology), 34, $1-52$.

Colmenar, J., Villas, E., Gutiérrez-Marco, J. C. \& Zamora, S. 2015. Ordovician to Devonian echinoderm faunas from the Iberian chains. In Progress in Echinoderm Palaeobiology (Zamora, S. \& Rábano, I., eds), Cuardenos del Museo Geominero, 19, 231-246.

David, B. \& Mooi, R. 1998. Major events in the evolution of echinoderms viewed by the light of embryology. In Echinoderms: San Francisco (Mooi, R. \& Telford, M., eds), pp. 21-28. Balkema, Rotterdam.

David, B., Mooi, R. \& Telford, M. 1995. The ontogenetic basis of Lovén's Rule clarifies homologies of the echinoid peristome. In Echinoderm Research (Emson, R. H., Smith, A. B. \& Campbell, A., eds), pp. 155-164. Balkema, Rotterdam.

Eichwald, E. 1840. Sur le systême silurien de l'Esthonie. St. Petersburg, 1, 222 pp.

Eichwald, E. 1856. Beitrag zur geographischen Verbreitung der fossilien Thiere Russlands. Alte Periode. Bulletin de la Société Impériale des Naturalistes de Moscou, 29, 88-127.

Eichwald, E. 1860. Lethaea Rossica ou Paléontologie de la Russie, décrite et figurée. Premier volume. Seconde Section de l'ancienne Période en deux sections. E. Schweizerbart, Stuttgart, XIX+1-1657 pp.

Foerste, A. F. 1914. Notes on Agelacrinidae and Lepadocystinae with descriptions of Thresherodiscus and Brockocystis. Bulletin of the Scientific Laboratories of Denison University, 17, 399-487.

Frest, T. J. 1983. Systematics and paleoecology of new Holocystites fauna taxa (Echinodermata, Blastozoa: Diploprita) from the Wenlockian (Silurian) of Indiana. Chapter 7. In Studies of Silurian Echinoderms. Unpublished $\mathrm{Ph}$ D thesis, University of Iowa.

Frest, T. J., Strimple, H. L. \& Paul, C. R. C. 2011. The North American Holocystites fauna (Echinodermata: Blastozoa: Diploporita): paleobiology and systematics. Bulletins of American Paleontology, 380, 1-142.

Guensburg, T. E., Sprinkle, J., Mooi, R. \& Lefebvre, B. 2021. Evolutionary significance of the blastozoan Eumorphocystis and its pseudo-arms. Journal of Paleontology, 95, 327-343.

Hisinger, W. 1828. Anteckningar i Physik och Geognosi under resor uti Sverige och Norrige. Vol. 4, Stockholm, x + 258 pp.

Jaekel, O. 1899. Stammesgeschichte der pelmatozoen. 1. Thecoidea und Cystoidea. Julius Springer: Berlin; 442 pp.

Jaekel, O. 1918. Phylogenie und System der Pelmatozoen. Paläontologisches Zeitschrift, 3, 1-128. 
Jaekel, O. 1926. Über zwei Cystoideen und ihre morphologische Bewertung. Norsk Geologisk Tiddskrift, 9, 19-22.

Kesling, R. V. 1968. Cystoids. In Treatise on Invertebrate Paleontology, Part S, Echinodermata 1 (1) (Moore, R. C., ed.), pp. S85-S267. Geological Society of America and University of Kansas: New York and Lawrence.

Kröger, B. \& Aubrechtová, M. 2019. The cephalopods of the Kullsberg Limestone Formation, Upper Ordovician, central Sweden and the effects of reef diversification on cephalopod diversity. Journal of Systematic Palaeontology, 17, 961-995.

Lefebvre, B, Ghobadipour, M. \& Nardin, E. 2005. Ordovician echinoderms from the Tabas and Damghan regions, Iran: palaeobiogeograhical implications. Bulletin de la Société Géologique de France, 176, 231-242.

Meléndez, B. 1944. Nuevos datos para le estratigrafia del Paleozoico aragonés. Boletín de la Real Sociedad Española de Historia Natural, 42, 129-150.

Mergl, M. \& Prokop, R. J. 2006. Lower Ordovician cystoids (Diploporita, Rhombifera) from the Prague Basin (Czech Republic). Bulletin of Geosciences, 81, 1-15.

Mooi, R. \& David, B. 1997. Skeletal homologies of echinoderms. In Geobiology of Echinoderms (Waters, J. A. \& Maples., C. G., eds), Paleontological Society Papers, 3, 305-335.

Müller, J. 1854. Über den Bau der Echinodermen. Abhandlungen der königlichen preussischen Akademie der Wissenschaften, aus dem Jahre 1853, 123-219.

Neumayr, M. 1889. Die Stämme des Thierreiches. 1. Wirbellose Thiere. Tempsky, Vienna and Prague, 603 pp.

Parsley, R. L. 1982. Eumorphocystis. In Echinoderm Faunas from the Bromide Formation (Middle Ordovician) of Oklahoma (Sprinkle, J., ed.), University of Kansas Paleontological Contributions, Monograph, 1, 280-288.

Paul, C. R. C. 1971. Revision of the Holocystites fauna (Diploporita) of North America. Fieldiana: Geology, 24, 1-166.

Paul, C. R. C. 1972. Morphology and function of exothecal porestructures in cystoids. Palaeontology, 15, 1-28.

Paul, C. R. C. 1973. British Ordovician Cystoids, part 1. Monographs of the Palaeontographical Society, 127(536), 1-64.

Paul, C. R. C. 1984. British Ordovician Cystoids, part 2 Monographs of the Palaeontographical Society, 136(563), 65-152.

Paul, C. R. C. 1988. The phylogeny of the cystoids. In Echinoderm Phylogeny and Evolutionary Biology (Paul, C. R. C. \& Smith, A. B., eds), pp. 199-213. Oxford Science Publications, Oxford.

Paul, C. R. C. 1997. Second addendum to Part 1. British Ordovician Cystoids, part 3. Monographs of the Palaeontographical Society, 151(604), 153-155.

Paul, C. R. C. 2017. Testing for homologies in the axial skeleton of primitive echinoderms. Journal of Paleontology, 91, 582603.

Paul, C. R. C. 2018. Prokopius, a new name for "Hippocystis sculptus" Prokop, 1965 and the status of the genus Hippocystis Bather, 1919 (Echinodermata; Diploporita). Bulletin of Geosciences, 93, 337-346.

Paul, C. R. C. \& Fone, W. 1997. Third addendum to Part 1. British Ordovician Cystoids, part 3. Monographs of the Palaeontographical Society, 151(604), 155-159.

Paul, C. R. C. \& Gutiérrez-Marco, J. C. 2020. Enodicalix (Diploporita, Aristocystitidae), a new echinoderm genus from the Middle Ordovician of Spain. Geologica Acta, 18.3, $1-8$.

Paul, C. R. C. \& Hotchkiss, F. R. C. 2020. Origin and significance of Lovén's Law in echinoderms. Journal of Paleontology, 94, 1089-1102.

Paul, C. R. C. \& Toom, U. 2021. Cystoblastus and the origin of the Hemicosmitoida (Echinodermata: Blastozoa). Estonian Journal of Earth Sciences, 70, 165-181.

Prokop, R. J. 1964. Sphaeronitoidea Neumayr of the Lower Palaeozoic of Bohemia (Cystoidea, Diploporita). Sbornik Geologických véd, Paleontologie, 3, 7-37.

Prokop, R. J. \& Petr, V. 1999. Echinoderms in the Bohemian Ordovician. Journal of the Czech Geological Society, 44, 63-68.

Regnéll, G. 1945. Non-crinoid Pelmatozoa from the Paleozoic of Sweden. A taxonomic study. Meddelanden från Lunds Geologisk-Mineralogiska Institution, 108, 1-255.

Sheffield, S. L. \& Sumrall, C. D. 2019a. A re-interpretation of the ambulacral system of Eumorphocystis (Blastozoa, Echinodermata) and its bearing on the evolution of early crinoids. Palaeontology, 61, 163-173.

Sheffield, S. L. \& Sumrall, C. D. 2019b. The phylogeny of the Diploporita: a polyphyletic assemblage of blastozoan echinoderms. Journal of Paleontology, 93, 740-752.

Smith, A. B. 1980. Stereom microstructure of the echinoid test. Special Papers in Palaeontology, 25, 1-81.

Sprinkle, J. 1973. Morphology and evolution of blastozoan echinoderms. Special Publication, Museum of Comparative Zoology, Harvard, 1-284.

Sprinkle, J. \& Guensburg, T. E. 2001. Growing a stalked echinoderm within the Extraxial-Axial Theory. In Echinoderms 2000 (Barker, M. F., ed.), pp. 59-65. A. A. Balkema, Lisse.

Sumrall, C. D. \& Gahn, F. J. 2003. The phylogenetic position and morphological reinterpretation of two enigmatic edrioasteroids from Canada. Geological Society of America, Abstracts with Programs, 35(6), 165.

Sumrall, C. D. \& Gahn, F. J. 2006. Morphological and systematic reinterpretation of two enigmatic edrioasteroids (Echinodermata) from Canada. Canadian Journal of Earth Sciences, 43, 497-507.

Sumrall, C. D., Sprinkle, J. \& Guensburg, T. E. 2001. Comparison of flattened blastozoan echinoderms: insights from the new early Ordovician eocrinoid Haimacystis rozhnovi. Journal of Paleontology, 75, 985-992.

Thomka, J. R. \& Brett, C. E. 2014. Diploporite (Echinodermata: Blastozoa) thecal attachment structures from the Silurian of southeastern Indiana. Journal of Paleontology, 88, 179-186.

Ubaghs, G. 1953. Notes sur Lichenoides priscus Barrande, eocrinoïde du Cambrien Moyen de la Tchécoslovaquie. Bulletin de l'Institut royal des Sciences Naturelles de Belgique, 29, 1-24.

Ubaghs, G. 1968. Eocrinoidea. In Treatise on Invertebrate Paleontology, Part S Echinodermata 1 (Moore, R. C., ed.), pp. S455-S495. Geological Society of America and University of Kansas: New York and Lawrence.

Volborth, A. von 1846. Über die russischen Sphaeroniten, eingeleitet durch einige Betrachtungen über die Arme der Cystideen. Verhandlungen Russisch-Kaiserlichen Mineralogischen Gesellschaft zu St. Petersburg, 1845-1846, 161198. 


\title{
Diplopoorne okasnahkne Glyptosphaerites (Echinodermata, Blastozoa) ja diplopooride päritolu
}

\author{
Christopher R. C. Paul ja Ursula Toom
}

Glyptosphaerites on varreta diploporiid, mida iseloomustavad viis üle karika ulatuvat paljude brahhioolplaadikestega ambulakraali, millel puudub täielikult nii põhja- kui ka katteplaadistik. Glyptosphaerites'e toiduvagudel ei ole süsteemset seost karika plaadistusega. Toiduvaod kasvavad välja suust, mida ümbritsevad viis radiaalplaati ja üks vaheplaat. Suud katab 11 plaadist koosnev suulagi. Sellised tunnused esinevad enamikul sugukonna Sphaeronitidae esindajatest. Traditsiooniliselt on Glyptosphaerites't seostatud diploporiididega, millel on vars ning ambulakraalsüsteem, mille moodustavad kahes reas paiknevad põhjaplaadid. Vaheldumisi vasakule ja paremale pöörduva ambulakraali iga pöörde lõpus asetseb üks brahhioolplaat. Selline diploporiid on Protocrinites, millel on ambulakraalide ja suu kohal katteplaadid, kuid puudub suulagi. Glyptosphaerites ja Protocrinites on diploporiidide kahe erineva rühma tüüpilised esindajad, mida käesolevas töös nimetatakse vastavalt Anambulacralia ja Ambulacralia. Kesk-Kambriumi 'eokrinoid' Lichenoides on vanim teadaolev anambulakraal.

Glyptosphaerites leuchtenbergi diplopoorid tekkisid plaatide ühenduskohtadele ühtse, risti üle plaatide servade asetseva kanalina. Plaadi kasvades liikus diplopoor ühele plaadile ja ühenduskohta tekkis uus kanal. Plaadi edasine kasv suurendas kahe diplopoori eraldumist ning nendevaheline standardkaugus saavutati siis, kui mõlemad asetsesid ühel plaadil. Paralleelsed diplopoorid asetsevad risti plaatide ühenduskohtadega. Glyptosphaerites leuchtenbergi diplopoorid kasvasid enamasti ühenduskohtades ainult ühele plaadile ja sageli koondusid selle suupoolsele servale. 